\title{
Prevalence and control of hypertension in a Niger Delta semi urban community, Nigeria
}

\author{
Ismail A. SULEIMAN, Ebubechukwu O. AMOGU, Kehinde A. GANIYU. \\ Received (first version): 29-Mar-2012 Accepted: 24-Feb-2013
}

\begin{abstract}
*
Background: Hypertension is a public health problem worldwide, but the prevalence in Amassoma, Southern ljaw Local Government Area is not known.

Objective: To investigate the prevalence of hypertension in the locality and the extent of control in diagnosed cases.

Methods: It is a prospective study involving interviewing. Four hundred adults aged 20 years and above selected through stratified random sampling across the various compounds called "AMA"; a unit of settlement comprising extended families of common ancestors. A self-developed, validated and pretested interviewer-administered questionnaire on demographics, predisposing factors, and medication history was used. In addition, measurement of respondents' blood pressure, weight and height was carried out. The Body Mass Index calculated and the data were appropriately analysed.

Results: The response rate of questionnaire distribution was $100.0 \%$ being interviewer administered alongside weight, height and blood pressure measurement. Majority of respondents were female. Almost half of respondents (46.5\%) had their BMl above normal, $15.3 \%$ (61) of which falls within the obese region $\left(>30.0 \mathrm{~kg} / \mathrm{m}^{2}\right)$. The mean (SD) systolic blood pressure among males was 133.3 (3.2) $\mathrm{mmHg}$ and that of females was 127.4 (3.0) while the mean (SD) diastolic blood pressures were $86.2(1.7)$ and 83.9 (2.4) for males and females respectively. Crude prevalence rate of hypertension in the community was $15.0 \%(60)$ out of which $13.8 \%$ (55) were previously diagnosed. The hypertension was that of Stage I in $11.5 \%$ (46) and Stage II in 3.5\% (14). Hypertension prevalence was slightly higher in males $(18.8 \%)$ than that of the females $(12.5 \%)(p=0.0889)$, Relative Risk $(\mathrm{RR})=1.500[95 \% \mathrm{Cl} 0.9422: 2.388]$. The prevalence rate among 40 years and above was $41.6 \%$ (42/101) who also constituted $70.0 \%(42 / 60)$ of participants with hypertension in the survey and $10.5 \%(42 / 400)$ of the total. Of the previously
\end{abstract}

\footnotetext{
*Ismail A. SULEIMAN. B.Pharm, M.Pharm, Ph.D. Senior Lecturer. Department of Clinical Pharmacy and Pharmacy Practice. Faculty of Pharmacy, Niger Delta University, Wilberforce Island, Bayelsa State (Nigeria).

Ebubechukwu O. AMOGU. B.Pharm. Pharmacist.

Department of Clinical Pharmacy and Pharmacy Practice, Faculty of Pharmacy, Niger Delta University, Wilberforce Island, Bayelsa State (Nigeria).

Kehinde A. GANIYU. B.Pharm, MSc. Lecturer II.

Department of Clinical Pharmacy and Pharmacy Practice, Faculty of Pharmacy, Niger Delta University, Wilberforce Island, Bayelsa State (Nigeria).
}

diagnosed cases of hypertension, only 31\% (17/55) were taking their drugs during the survey and only $12.7 \%(07 / 55)$ had regular adherence to medication and adequate BP control was achieved in $7.3 \%$ $(04 / 55)$. Majority of the patients on drugs $(21.8 \%)$ $(12 / 55)$ were either taking methydopa as monotherapy or in combination with amiloride and hydrochlorothiazide. Other drugs being taken by patients include lisinopril, propranolol, amlodipine, atenolol, nifedipine and low dose aspirin.

Conclusion: The prevalence of hypertension in the semi urban community is $15.0 \%$ with a prehypertension in another $23.5 \%$. There was poor control of blood pressure among previously hypertensive patients.

Keywords: Hypertension; Prevalence; Nigeria

\section{PREVALENCIA Y CONTROL DE LA HIPERTENSIÓN EN UNA COMUNIDAD SEMI-URBANA DEL DELTA DEL NIGER, NIGERIA}

\section{RESUMEN}

Antecedentes: La hipertensión es un problema de salud pública mundial, pero la prevalencia en Amassoma, Región del gobierno local de Southern Ijaw, es desconocida.

Objetivo: Investigar la prevalencia de hipertensión en la localidad y el grado de control de los casos diagnosticados.

Métodos: Estudio prospectivo que incluyó una entrevista. Se seleccionó a 400 adultos de 20 años o más mediante un muestreo aleatorio estratificado en los varios sectores llamados “AMA”; la unidad familiar comprendía las familias con los antepasados comunes. Se utilizó un cuestionario auto-desarrollado, validado y pre-testeado administrado por encuestador sobre demografía, factores predisponentes y medicación. Además, se realizó una medición de presión arterial, peso y altura de los respondedores. Se calculó el índice de masa corporal y se analizaron los datos pertinentemente.

Resultados: La tasa de respuesta de la distribución del cuestionario fue del $100 \%$, siendo el entrevistador quien midió peso, altura y presión arterial. La mayoría de los respondentes eran mujeres. Casi la mitad de los respondentes (46,5\%) tenían un IMC por encima de lo normal, 15,3\% (61) de ellos estaban en la zona de obesidad (>30,0 $\mathrm{kg} / \mathrm{m}^{2}$ ). La media (DE) de la presión arterial sistólica entre hombres era de $133,3(3,2) \mathrm{mmHg}$ y en mujeres de 127,4 $(3,0)$, mientras que la media (DE) de la presión arterial diastólica fue de 86,2 $(1,7)$ y de $83,9(2,4)$ para hombres y mujeres, 
respectivamente. La tasa de prevalencia cruda de hipertensión en la comunidad fue del 15,0\% (60) de los que el 13,8\% (55) habían sido previamente diagnosticados. La hipertensión era de estadio I en el 11,5\% (46) y de estadio II en el 3,5\% (14). La prevalencia de hipertensión fue ligeramente mayor en hombres $(18,8 \%)$ que en mujeres $(12,5 \%)$ $(\mathrm{p}=0,0889$; riesgo relativo $(\mathrm{RR})=1,500[\mathrm{IC} 95 \%=$ $0,9422: 2,388]$. La tasa de prevalencia entre los de 40 años o más fue del 41,6\% (42/101) que también constituían el 70,0\% (42/60) de los participantes con hipertensión en el estudio y el 10,5\% (42/100) del total. De los casos previamente diagnosticados de hipertensión, sólo el 31\% (17/55) estaban tomando medicamentos regularmente durante la encuesta y sólo el $12,7 \%$ cumplían regularmente la medicación y se alcanzó el control adecuado de la presión arterial en el 7,3\% (4/55). La mayoría de los pacientes medicados $(21,8 \%)(12 / 55)$ estaban o con metildopa en monoterapia o en combinación de amiloride and hydrochlorothiazide. Otros medicamentos utilizados incluían lisinopriolo, propranolol, amlodipina, atenolol, nifedipina y bajas dosis de aspirina.

Conclusión: La prevalencia de hipertensión en el área semi-urbana es del 15,0\% con una prehipertensión en otro 23,5\%. Había in pobre control de la presión arterial entre los pacientes previamente diagnosticados.

Palabras clave: Hipertensión; Prevalencia; Nigeria

\section{INTRODUCTION}

Hypertension is widely known to be a major public health problem ${ }^{1,2}$ and has serious impact on individuals' quality of life and on economy ${ }^{3}$ with its huge attendant direct and indirect cost implications. ${ }^{4}$ The annual national direct cost implications of hypertension alone has been estimated to be in excess of NGN450 billion (USD3 billion) in Nigeria. ${ }^{4}$ It is also the commonest cause of sudden unexpected natural death in Nigeria. ${ }^{5,6}$ In the study of patterns of cardiovascular diseases in many centres in Nigeria, hypertension was ranked first ${ }^{7}$, and is the medical illness most frequently diagnosed in elderly Nigerians. ${ }^{8}$

Prevalence of hypertension across the world indicates progressive increment. The rate is higher in western world and a consistent gradient of hypertension prevalence rising from $16 \%$ in West Africa to $26 \%$ in the Caribbean and $33 \%$ in the United States was reported in $1997 . .^{9}$ In 1993, a prevalence rate of $4.5 \%$ among rural dwellers and of $8 \%$ to $13 \%$ in the town was reported in Ghana ${ }^{10}$, but in 2003 a prevalence rate of $28.3 \%$ (crude) and $27.3 \%$ (age-standardized) was reported. ${ }^{11}$

In Nigeria, the age-adjusted prevalence of hypertension was reported to be $14.5 \%$ in $1997 .{ }^{9} \mathrm{~A}$ crude prevalence of $21 \%(23.3 \%$ in males and $16.4 \%$ in females) in $2005^{3}, 36.6 \%$ in $2008^{12}$ and $22 \%$ in $2011^{13}$ were reported for south western Nigeria. In South Eastern part of Nigeria, $21 \%{ }^{14}$ and $42 \%{ }^{15}$ prevalence rates were reported. In SouthSouth Nigeria, a prevalence rate of $16 \%$ and $12 \%$ was reported among men and women respectively in $2007 .{ }^{16}$ Not much work has been published on the study of prevalence of hypertension in SouthSouth region of Nigeria particularly in Bayelsa State making such study imperative.

With poor detection, treatment and control $^{17}$ and challenges of poor awareness ${ }^{18}$, and weak capacity for management, prevention programmes ${ }^{19}$ still remain the most cost effective options. Reliable prevention strategies depend on precise estimates of prevalence of hypertension in the community ${ }^{12}$ as well as epidemiological characteristics. ${ }^{3}$

With increasing urbanisation in the community particularly since a university was sited coupled with paucity of published data on prevalence of hypertension in this region, the study was designed to investigate the prevalence of hypertension, its epidemiological characteristics and extent of BP control among hypertensive population in the locality.

\section{METHODS}

It is a prospective study. Approval for the study was obtained from the institutional research board of the Niger Delta University. The setting for this study was a semi urban community of Amassoma in Southern ljaw, Bayelsa State. Southern ljaw has a coastline of approximately $60 \mathrm{~km}$ on the Bight of Benin and a population of 319,413 based on 2006 census. The two major towns in Southern ljaw are Amassoma (the most populous) and Ogboinbirin. Others are Oporoma, Ekowe, Peremobiri, Otuan, Angiama, Korokorosei, Ondewari and numerous villages. Community and youth leaders were contacted with introductory letter from the University and their consents obtained. Detailed of the purpose and procedure were made known to the participants. . The door-to- door house survey took place between February and May 2011. A target population of 384 was obtained using a sample size calculator at $95 \%$ confidence level and $5 \%$ confidence interval (www.surveysystem.com/sscalc.html). ${ }^{20}$

Amassoma town which is made up of Twenty Two compounds called 'AMA'; a unit of settlement comprising extended families of common ancestors was stratified into eighteen enumeration areas based on population density. Twenty to Thirty consented adults aged 20 years and above were randomly selected in each compound. These include 30 respondents each for three very large compounds; Efeke Ama, Okori Ama and Ayaogbo Ama, Twenty Five each for Okoloba Ama and Oporoma Ama. The rest thirteen enumeration areas had an average of twenty respondents each making a total of 400 participants.

A questionnaire was self-developed, validated and pretested. Questions related to epidemiological characteristics such as demographics, predisposing factors, previous diagnosis of hypertension and relevant medication history were included. Also included were fields for blood pressure, weight and body mass index record. The questionnaire was 


\begin{tabular}{|c|c|c|c|c|c|c|c|}
\hline \multirow{2}{*}{$\begin{array}{l}\text { Age } \\
\text { (Years) }\end{array}$} & \multicolumn{3}{|c|}{ Sex of Respondent } & \multicolumn{4}{|c|}{ Hypertension Type } \\
\hline & $\begin{array}{l}\text { Male } \\
\mathrm{N}(\%)\end{array}$ & $\begin{array}{c}\text { Female } \\
\mathrm{N}(\%)\end{array}$ & $\begin{array}{l}\text { Total } \\
\mathrm{N}(\%) \\
\end{array}$ & $\begin{array}{c}\text { ISH } \\
\mathrm{N}(\%)\end{array}$ & $\begin{array}{c}\text { IDH } \\
\mathrm{N}(\%) \\
\end{array}$ & $\begin{array}{c}\text { Systolic/Diastolic } \\
\mathrm{N}(\%)\end{array}$ & $\begin{array}{l}\text { Total } \\
\mathrm{N}(\%) \\
\end{array}$ \\
\hline $20-30$ & $57(14.3)$ & $127(31.8)$ & $184(46.0)$ & $0(0.0)$ & $1(1.6)$ & $6(10.0)$ & $7(11.7)$ \\
\hline $31-40$ & $56(14.0)$ & $59(14.8)$ & $115(28.8)$ & $2(3.3)$ & $5(8.3)$ & $6(10.0)$ & $13(21.6)$ \\
\hline $41-50$ & $17(4.3)$ & $27(6.8)$ & $44(11.0)$ & $2(3.3)$ & $5(8.5)$ & $7(11.7)$ & $14(23.3)$ \\
\hline $51-60$ & $18(4.5)$ & $13(3.3)$ & $31(7.8)$ & $4(6.6)$ & $3(5.0)$ & $7(11.7)$ & $14(23.3)$ \\
\hline$>60$ & $12(3.0)$ & $14(3.5)$ & $266.5)$ & $0(0.0)$ & $1(1.6)$ & $11(18.3)$ & $12(20.0)$ \\
\hline Total & $160(40.0)$ & $240(60.0)$ & $400(100.0)$ & $8(13.3)$ & $15(25.0)$ & $37(61.7)$ & $60(100.0)$ \\
\hline
\end{tabular}

Male and Female Age distribution chi-square $=14.523$, df $4, p=0.0058$

ISH: Isolated Systolic Hypertension, IDH: Isolated Diastolic Hypertension

interviewer administered to participants alongside blood pressure, height and weight measurement.

Height was measured without shoes using a wooden platform and a height rule to the nearest $0.5 \mathrm{~cm}$ while the weight was measured to the nearest $0.5 \mathrm{~kg}$, using a bathroom weighing scale (Hamson Scale). The Body Mass Index (BMI) was calculated as weight in kilograms divided by the square of the height in meter $\left(\mathrm{m}^{2}\right)$. Blood pressure (BP) was measured after the participants had seated for at least 5 minutes with a validated electronic BP monitor (Omron MX2 Basic, Omron Healthcare Co LTD, China). The MX2 Basic includes a standard cuff of $145 \mathrm{~cm}(\mathrm{~W})$ by $480 \mathrm{~cm}$ (L) for an arm circumference ranging from 23-32 $\mathrm{cm}$. Aneroid sphygmomanometer with stethoscope, with adult inflation system and cotton cuff (Medicare instrument (WUXI) LTD, China was used to validate $\mathrm{BP}$ electronic monitor. Three readings were taken at interval of three minutes, two from the left and one from the right arm. The first reading was discarded the mean of the last two readings recorded and used for analysis. The participants were visited on two separate occasions two weeks apart and the same procedure followed each time. Hypertension was defined as a systolic BP $\geq 140 \mathrm{mmHg}$ and/or a diastolic blood $B P \geq 90 \mathrm{mmHg}$ or being on drug therapy for hypertension. This BP threshold was based on guidelines as recommended by the seventh Joint National Committee on Prevention, Detection, Evaluation and Treatment High Blood Pressure (JNCVII) and World Health Organisation. $^{21,22}$ Completed questionnaires were retrieved and the data collected entered into the computer. Statistical Package for Social Sciences version 16 (SPSS Inc, Chicago Illinois, USA) and GraphPad Prism for Windows Instat Version 3 (GraphPad Software San Diego, CA USA) were used in data analysis. Data were presented using descriptive statistics. Chi square test was used for categorical data. Mean values of blood pressure for male and female respondents were compared using student-t test. At $95 \%$ confidence interval, a 2-tailed p-value less than 0.05 was considered significant.

\section{RESULTS}

Of the total participants population $(\mathrm{N}=400)$ majority were females $(n=240 ; 60 \%)$ out of which $10.8 \%$ $(n=43)$ were pregnant. Age of participants ranged from 20 years to 60 years and above. Thirty Seven percent $(n=149)$ were civil servants, $18.5 \%$ were traders among others. Sixty three percent $(n=251)$ were married. The mean systolic blood pressure among males was $133.3(\mathrm{SD}=3.2) \mathrm{mmHg}$ and that of females was $127.4(S D=3.0)$ while the mean diastolic blood pressures were $86.2(\mathrm{SD}=1.7)$ and 83.9 (SD=2.4) for males and females respectively. The overall variation in blood pressure between male and female participants was very significant $(p<0.0001)$. See Tables 1 and 2 for details

Only $48.5 \%$ of participants had their BMI within the normal range of $18.5-24.99 \mathrm{~kg} / \mathrm{m}^{2}$. Obesity was observed in $15.3 \%$. See Table 3 for details.

Hypertension prevalence was higher in males $(18.8 \%)$ which is not statistically significantly different from that of the females $(12.5 \%)$; $\mathrm{P}=0.0889$, relative risk $(\mathrm{RR})=1.500 \quad[95 \% \mathrm{Cl}$ $0.9422: 2.388]$, risk difference $(R D)=0.06250[95 \% \mathrm{Cl}$ $0.0089: 0.1339]$. Inclusion of pre hypertensive group to hypertensive proportion gives an extremely significant difference between males and females $(p<0.0001) ; \quad R R=1.800 \quad[95 \% \mathrm{Cl} \quad 1.407: 2.303]$, $\mathrm{RD}=0.5250 \quad[95 \% \mathrm{Cl} \quad 0.4445: 0.6039] . \quad$ Crude prevalence rate of hypertension in the community was $15.0 \%$ (60) out of which $13.8 \%$ (55) were previously diagnosed. See Table 2 for details. Of the previously diagnosed cases of hypertension, only $31 \%(17 / 55)$ were taking their drugs during the

\begin{tabular}{|c|c|c|c|c|c|}
\hline Variable & $\begin{array}{l}\text { Normal BP } \\
\mathrm{N}(\%)\end{array}$ & $\begin{array}{c}\text { Pre Hypertension } \\
\text { N (\%) }\end{array}$ & $\begin{array}{l}\text { Stage I } \\
\text { Hypertension } \\
\text { N (\%) }\end{array}$ & $\begin{array}{c}\text { Stage II } \\
\text { Hypertension } \\
\mathrm{N}(\%)\end{array}$ & $\begin{array}{l}\text { Total } \\
\text { N (\%) }\end{array}$ \\
\hline $\begin{array}{lr}\text { Sex } & \text { Male } \\
& \text { Female } \\
\text { Total } & \\
\end{array}$ & $\begin{array}{c}76(19.0) \\
170(42.5) \\
246(61.5) \\
\end{array}$ & $\begin{array}{l}54(13.5) \\
40(10.0) \\
94(23.5) \\
\end{array}$ & $\begin{array}{c}22(5.5) \\
24(6.0) \\
46(11.5) \\
\end{array}$ & $\begin{array}{c}8(2.0) \\
6(1.5) \\
14((3.5) \\
\end{array}$ & $\begin{array}{c}160(40.0) \\
240(60.0) \\
400(100.0) \\
\end{array}$ \\
\hline $\begin{array}{r}20-30 \\
31-40 \\
41-50 \\
51-60 \\
>60\end{array}$ & $\begin{array}{l}142(35.5) \\
71(17.8) \\
22(5.5) \\
5(1.3) \\
6(1.5)\end{array}$ & $\begin{array}{l}36(9.0) \\
32(8.0) \\
11(2.8) \\
11(2.8) \\
4(1.0)\end{array}$ & $\begin{array}{c}6(1.5) \\
10(2.5) \\
10(2.5) \\
9(2.3) \\
11(2.8)\end{array}$ & $\begin{array}{l}0(0.0) \\
2(0.5) \\
1(0.3) \\
6(1.5) \\
5(1.3) \\
14(25)\end{array}$ & $\begin{array}{c}184(46.0) \\
115(28.8) \\
44(11.0) \\
31(7.8) \\
26(6.5)\end{array}$ \\
\hline $\begin{array}{l}\text { Total } \\
\text { Blood Pressure: }\end{array}$ & $\frac{246(61.5)}{3 P(\mathrm{mmHg})}=$ & $\begin{array}{l}94(23.5) \\
19 / 60-79, \mathrm{P} \\
59 / 90-99 \mathrm{~s}\end{array}$ & $\begin{array}{l}46(11.5) \\
\text { ensive } \geq 12\end{array}$ & $\begin{array}{l}14(3.5) \\
-89\end{array}$ & $400(100.0)$ \\
\hline
\end{tabular}




\begin{tabular}{|c|c|c|c|c|c|}
\hline $\mathrm{BMI}\left(\mathrm{kg} / \mathrm{m}^{2}\right)$ & $\begin{array}{l}\text { Normal BP } \\
\quad \mathrm{N}(\%)\end{array}$ & $\begin{array}{c}\text { Pre Hypertension } \\
\text { N (\%) }\end{array}$ & $\begin{array}{c}\text { Stage I } \\
\text { Hypertension } \\
\mathrm{N}(\%)\end{array}$ & $\begin{array}{l}\text { Stage II } \\
\text { Hypertension } \\
\text { N (\%) }\end{array}$ & $\begin{array}{l}\text { Total } \\
\mathrm{N}(\%)\end{array}$ \\
\hline $\begin{array}{c}<18.5 \\
18.5-24.99 \\
25.0-29.99 \\
30.0-34.99 \\
35.0-39.99 \\
>40 \\
\text { Total }\end{array}$ & $\begin{array}{c}16(4.0) \\
126(31.5) \\
77(19.3) \\
20(5.0) \\
6(1.5) \\
1(0.3) \\
246(61.5)\end{array}$ & $\begin{array}{c}3(0.8) \\
47(11.8) \\
28(7.0) \\
11(2.8) \\
3(0.8) \\
2(0.5) \\
94(23.5)\end{array}$ & $\begin{array}{c}0(0.0) \\
15(3.8) \\
14(3.5) \\
6(1.5) \\
6(1.5) \\
5(1.3) \\
46(11.5)\end{array}$ & $\begin{array}{c}0(0.0) \\
6(1.5) \\
7(1.8) \\
1(0.3) \\
0(0.0) \\
0(0.0) \\
14(3.5)\end{array}$ & $\begin{array}{c}19(4.8) \\
194(48.5) \\
126(31.5) \\
38(9.5) \\
15(3.8) \\
8(2.0) \\
400(100.0)\end{array}$ \\
\hline \multicolumn{6}{|c|}{$\begin{array}{c}\text { BMI }\left(\mathrm{kg} / \mathrm{m}^{2}\right): \text { Underweight }<18.5, \text { Normal weight }=18.5-24.99, \text { Overweight }=25.0-29.99, \\
\text { Obesity Class I }=30.0-34.99 \text { Obesity Class II = 35.0-39.99, Morbid Obesity }=\geq 40 . \\
\text { Blood Pressure: Normal BP }(\mathrm{mmHg})=<90-119 / 60-79, \text { Pre-Hypertensive } \geq 120-139 / 80-89, \\
\text { Stage I Hypertension }=140-159 / 90-99, \text { Stage II Hypertension }=\geq 160 / 100\end{array}$} \\
\hline
\end{tabular}

survey, and only $12.7 \% \quad(07 / 55)$ had regular adherence to medication and adequate BP control was achieved in only $7.3 \%(04 / 55)$. The prevalence rate among 40 years and above was $41.6 \%$ $(42 / 101)$ who also constituted $70.0 \%$ (42) of participants with hypertension in the survey. Proportions of participants with isolated systolic and isolated diastolic hypertension were $13.3 \%(08)$ and $25.0 \%$ (15) respectively. Majority of the patients on drugs $(21.8 \%)(12 / 55)$ were either taking methydopa as monotherapy or in combination with co-amilozide (moduretic). Other drugs being taken by patients include lisinopril, propranolol, amlodipine,atenolol, nifedipine and low dose aspirin.

Sixty five percent of hypertensive patients $(39 / 60)$ were either overweight or obese. A consistent gradient of hypertensive population proportion by BMI group population was observed rising from $0.0 \%$ in underweight to $10.8 \%$ for normal $\mathrm{BMI}$ to $16.7 \%, 18.4 \%, 40.0 \%$ and $62.0 \%$ for overweight, obesity class I, obesity class II and morbid obesity respectively. Overweight or obesity was more prevalent in females $(52.0 \%)$ as compared with males $(34.8 \%)$.

The occupations with very strong association with hypertension were civil service and trading both of which constituted $61.7 \%$ (37) of hypertensive population. It was $46.7 \%(n=60)$ for civil servants and $15.0 \%(n=60)$ for traders. Other risk factors include family history, smoking, alcohol, and diabetes mellitus. See Table 4 for details.

\section{DISCUSSION}

The estimated crude prevalence of $15.0 \%$ out of which $1.2 \%$ was newly diagnosed, observed for the southern ljaw community is similar to the one reported $(16 \%$ for males and $12 \%$ for females) in this region ${ }^{16}$ and some earlier studies in Nigeria., ${ }^{9,10}$ However, it is much lower as compared to the prevalence rate of $21 \%$ and $36.6 \%$ reported in the south western region. 3
Several factors could be responsible. The prevalence may be truly lesser in this region and the study centre in particular. One factor is that the community for this study still shares some things in common with rural settings unlike a more urbanized and more stressful study centre in south western Nigeria. Hypertension prevalence is usually lower in rural settings ${ }^{10}$ Another probable factor is that of diet which is known to play a role in hypertension. The most popular staple food in this community is plantain in various forms both as roasted or as porridge popularly called "kekefiya" in local dialect and always in combination with fish as reported ${ }^{23}$ and confirmed by the authors. Both fish and plantain has been reported differently to have beneficial effects on blood pressure. The people of this locality and the region which are riverine communities are traditionally fishermen, which have been heavily hampered due to oil exploration. They are known to eat a lot of fish which contains fish oils by far more than any region in Nigeria. Fish oils contain longchain polyunsaturated omega-3 fatty acids, more specifically, eicosapentaenoic acid (EPA) and docosahexaenoic acid (DHA). ${ }^{24,25}$ The American Heart Association recommends that people increase their intake of long-chain polyunsaturated omega-3 oils from certain type of fish or directly from fish oil supplement. ${ }^{24,25}$ Plantain on its own is also beneficial to the cardiovascular system including hypertensive patients. Its positive effects on arterioscleroses, hypertension as well as on oxidant stress have been reported and cited. ${ }^{26,27}$ Its high level of potassium makes it particularly beneficial in hypertension. ${ }^{27}$

Low hypertension prevalence, in about one-fifth of participants who drinks alcohol, may also be due to its beneficial effect if taken in moderation and can be contributory to relatively low overall prevalence rate among the populace. However, alcoholic pre hypertensive proportion needs to be warned to avoid drinking it in excess.

Poor adherence to therapy and poor control of

\begin{tabular}{|l|c|c|c|c|c|}
\hline Table 4. Risk Factors and Hypertension prevalence in a semi urban Niger Delta community \\
Observed Risk factor & $\begin{array}{c}\text { Normal BP } \\
\mathrm{N}(\%)\end{array}$ & $\begin{array}{c}\text { Pre Hypertension } \\
\mathrm{N}(\%)\end{array}$ & $\begin{array}{c}\text { Stage } \\
\text { Hypertension } \\
\mathrm{N}(\%)\end{array}$ & $\begin{array}{c}\text { Stage II } \\
\text { Hypertension } \\
\mathrm{N}(\%)\end{array}$ & $\begin{array}{c}\text { Total } \\
\mathrm{N}(\%)\end{array}$ \\
\hline Smoking & $32(8.0)$ & $18(4.5)$ & $5(1.3)$ & $2(0.5)$ & $57(14.3)$ \\
\hline Obesity & $27(6.8)$ & $16(4.0)$ & $17(4.3)$ & $1(0.3)$ & $61(15.3)$ \\
\hline Family history of hypertension & $55(13.8)$ & $25(6.3)$ & $14(3.5)$ & $3(0.8)$ & $97(24.3)$ \\
\hline Alcoholic drink & $68(17.0)$ & $71(17.8)$ & $26(6.5)$ & $10(2.5)$ & $175(43.8)$ \\
\hline Contraceptive drugs & $10(2.5)$ & $9(2.3)$ & $3(0.8)$ & $0(0.0)$ & $22(5.5)$ \\
\hline Diabetes mellitus & $1(0.25)$ & $5(1.3)$ & $4(1.0)$ & $2(0.5)$ & $12(3.0)$ \\
\hline
\end{tabular}


blood pressure among most participants with previously diagnosed hypertension indicates the need for enhanced enlightenment on drug and nondrug therapy to avoid complications. Poor adherence to medication is known to be common for chronic disease conditions such as diabetes and hypertension. ${ }^{28}$ Side effects such as reduced libido, poverty, inadequate knowledge about implications of non-adherence to medications may be responsible for poor adherence.

Higher prevalence rate of hypertension observed in age 40 years and above in the semi urban population is consistent with well-known fact, that age is a risk factor as earlier cited and reported. ${ }^{3,12}$ Higher absolute proportion in most categories of $\mathrm{BP}$ for males ranging from pre hypertension to stage II hypertension than female despite constituting smaller population group as a fraction of total also pointed to the risk nature of male gender. This contradicted the report by Adedoyin et al where higher prevalence was observed among females ${ }^{12}$ and in agreement with much earlier studies. ${ }^{29,30}$ The higher prevalence among civil servants and market men and women also pointed to their probable sedentary life style and greater tendencies towards western diet. A very high hypertension prevalence of $42 \%$ has been reported for market women in south eastern Nigeria. ${ }^{15}$ The consistent gradient observed in hypertensive population proportion within each BMl group with increasing BMI also indicated weight reduction programmes and avoidance of unnecessary weight gain through healthy diet as appropriate non drug and preventive modalities for hypertension prevention programmes. A further research into the staple food in this study centre and the state which consist predominantly of plantain in combination with fish as it relate to hypertension could be carried out and adopted if need be by people at risk of hypertension worldwide.
Limitations of the study include relatively small sample size and sampling for one town-the most populous in Southern ljaw Local Government Area and second most populous in Bayelsa State. Cautions need to be exercised in generalising the results among ljaw nation and south-south Nigeria. In addition, some participants could not communicate fluently in English, the use of pidgin English and interpreter minimises communication problems. A very small proportion of participants particularly students may not be of ljaw tribe. However, being a predominantly community based study, a great deal majority of participants are of Southern ljaw extraction, hence prevalence is a true reflection for the semi urban population.

\section{CONCLUSIONS}

The prevalence of hypertension in Amassoma community of Southern ljaw, Bayelsa State of Nigeria is $15.0 \%$ with a pre-hypertension in another $23.5 \%$ of the community. Blood pressure control among previously hypertensive patients is suboptimal.

\section{ACKNOWLEDGEMENTS}

The cooperation of the community youth and leaders is appreciated. The work was presented at International Society of Pharmacoeconomics and Outcomes Research (ISPOR) conference in June 2012 (2nd to 6th) which took place at Washington DC.US.

\section{CONFLICT OF INTEREST}

None declared

Funding Information: No funding was received.

\section{References}

1. Wolf-Maier K, Cooper RS, Banegas JR, Giampaoli S, Hense HW, Joffres M, Kastarinen M, Poulter N, Primatesta P Rodríguez-Artalejo F, Stegmayr B, Thamm M, Tuomilehto J, Vanuzzo D, Vescio F. Hypertension prevalence and blood pressure levels in 6 European countries, Canada, and the United States. JAMA. 2003;289(18):2363-9.

2. Murray CJ, Lopez AD. Mortality by cause for eight regions of the world. Global burden of disease. Lancet. 1997;349(9061):1269-76.

3. Erhun WO, Olayiwola G, Agbani EO, Omotosho NS. Prevalence of Hypertension in a University Community in SouthWest Nigeria. Afr J Biomed Res. 2005;8:15-9.

4. Suleiman IA, Lumor HA, Okubanjo OO. Pharmacoeconomic Evaluation of Antihypertemsive Therapy Using Cost of Illness Analysis in Olabisi Onabanjo University Teaching Hospital, Sagamu, Ogun State. Nigerian J Pharm 2005;37:31-

5. Amakiri CN, Akang EE, Aghadiuno PU, Odesanmi WO. A prospective study of coroner's autopsies in University College Hospital, Ibadan, Nigeria. Med Sci Law. 1997;37(1):69-75.

6. Aligbe JU, Akhiwu WO, Nwosu SO. Prospective study of coroner's autopsies in Benin City, Nigeria. Med Sci Law. 2002;42(4):318-24.

7. Bella AF, Bayewu O, Bamigboye A, Adeyemi ID, Ikuesan BA, Jegede RO. Pattern of medical illness in a community of elderly Nigerians. Cent Afr J Med. 1993;39(6):112-6.

8. Ogunniyi A, Baiyewu O, Gureje O, Hall KS, Unverzagt FW, Oluwole SA, Farlow MI, Komolafe, Hendrie HC. Morbidity pattern in a sample of elderly Nigerians resident in Idikan community, Ibadan. West Afr J Med. 2001;20(4):227-31.

9. Cooper R, Rotimi C, Ataman S, McGee D, Osotimehin B, Kadiri S, Muna W, Kingue S, Fraser H, Forrester T, Bennett F, Wilks R. The prevalence of hypertension in seven populations of West African origin. Am J Public Health. 1997;87(2):160-8.

10. Pobee JO. Community-based high blood pressure programs in sub-Saharan Africa. Ethn Dis. 1993;3(Suppl):S38-45. 
11. Amoah AG. Hypertension in Ghana: a cross-sectional community prevalence study in Greater Accra. Ethn Dis. 2003;13(3):310-5.

12. Adedoyin RA, Mbada CE, Balogun MO, Martins T, Adebayo RA, Akintomide A, Akinwusi PO. Akintomide Anthony and Patience O. A Prevalence and pattern of hypertension in a semiurban community in Nigeria. Eur J Cardiovasc Prev Rehabil. 2008;15(6):683-7.

13. Ekwunife OI, Aguwa CN. A meta-analysis of prevalence rate of hypertension in Nigerian populations, J Public Health Epidemiol. 2011;3(13):604-7. doi: 10.5897/JPHE11.104

14. Ekwunife OI, Udeogaranya PO, Nwafu IL. Prevalence, awareness, treatment and control of hypertension in a Nigerian population. Health 2011;2(7):731-5. DOI: 10.4236/health.2010.27111

15. Ulasi II, ljoma CK, Onwubere BJC, Arodiwe E, Onodugo O Okafor C . High prevalence and low awareness of Hypertension in a market population in Enugu, Nigeria. Int J Hypertens. 2011;2011:869675. doi: 10.4061/2011/869675.

16. Ofuya ZM. The Incidence of hypertension among selected population of adults Niger Delta Region of Nigeria. Southeast Asian J Trop Med Pub Health 2007;38(5):947-9.

17. Cappuccio FP, Micah FB, Emmett L, Kerry SM, Antwi S, Martin-Peprah R, Phillips RO, Plange-Rhule J, Eastwood JB. Prevalence, detection, management, and control of hypertension in Ashanti, West Africa. Hypertension. 2004;43(5):1017-22.

18. National Expert Committee on Non-Communicable Diseases (NCD, 1997). Non-Communicable diseases in Nigeria. Final report of a national survey. Federal Ministry of Health and Social Services, Lagos, 1997.

19. Muna WF. The importance of cardiovascular research in Africa today. Ethn Dis. 1993;3(Suppl):S8-12.

20. The Creative Research Systems. The complete survey software solution since 1982. Research Aids. Available at www.surveysystem.com/sscalc.html (Accessed February 2011).

21. Chobanian AV, Bakris GL, Black HR, Cushman WC, Green LA, Izzo JL Jr, Jones DW, Materson BJ, Oparil S, Wright JT Jr, Roccella EJ; National Heart, Lung, and Blood Institute Joint National Committee on Prevention, Detection, Evaluation, and Treatment of High Blood Pressure; National High Blood Pressure Education Program Coordinating Committee. The Seventh Report of the Joint National Committee on Prevention, Detection, Evaluation, and Treatment of High Blood Pressure: The JNC 7 Report. JAMA. 2003 May 21;289(19):2560-72.

22. World Health Organization-International Society of Hypertension Guidelines for the Management of Hypertension. Guidelines Subcommittee. Hypertension. 1999;17:1151-83.

23. Nigerian Arts and Culture directory. Available at: http://www.nacd.gov.ng/Bayelsa_State_Cuisines.htm (Accessed on 4th February, 2012).

24. Larsen HR. Fish oils and hypertension: Summaries of the latest research concerning fish oils and hypertension. Available at: http://www.oilofpisces.com/hypertension.html (Accessed 31ist January, 2012).

25. Kris-Etherton PM, Harris WS, Appel LJ; American Heart Association. Nutrition Committee. Fish Consumption, Fish Oil, Omega-3 Fatty Acids, and Cardiovascular Disease. Circulation. 2002;106(21):2747-57. doi: 10.1161/01.CIR.0000038493.65177.94

26. Osim EE, Ibu JO. The Effect of Plantains (Musa paradisiaca) on DOCA-Induced Hypertension in Rats. Pharm Biol. $1991 ; 29(1): 9-13$.

27. Imam MZ. Musa paradisiaca L and Musa sapientum L: A Phytochemical and Pharmacological Review. J App Pharm Sci 2011;1(5);14-20.

28. Adisa R, Fakeye TO, Fasanmade A. Medication adherence among ambulatory patients with type 2 diabetes in a tertiary healthcare setting in south western Nigeria. Pharm Pract 2011:9(2):72-82.

29. Akinkugbe OO, Ojo AO. The systemic blood pressure in a rural Nigerian population. Trop Geogr Med. 1968;20(4):34756.

30. Olatunbosun ST, Kaufman JS, Cooper RS, Bella AF. Hypertension in a black population: prevalence and biosocial determinants of high blood pressure in a group of urban Nigerians. J Hum Hypertens. 2000;14(4):249-57. 